\title{
Primary complement and antibody deficiencies in autoimmune rheumatologic diseases with juvenile onset: a prospective study at two centers
}

Mihaela Spârchez ${ }^{1,3^{*}}$, Iulia Lupan², Dan Delean ${ }^{3}$, Aurel Bizo ${ }^{1,3}$, Laura Damian4, Laura Muntean ${ }^{4,5}$, Maria Magdalena Tămaș ${ }^{4,5}$, Claudia Bolba ${ }^{3}$, Bianca Simionescu ${ }^{1,3}$, Cristina Slăvescu ${ }^{1,3}$, Ioana Felea ${ }^{4}$, Călin Lazăr ${ }^{3}$, Zeno Spârchez 6 and Simona Rednic ${ }^{4,5}$

\begin{abstract}
Background: Our aim was to investigate the prevalence and clinical relevance of inherited complement and antibody deficiency states in a large series of patients with various autoimmune rheumatologic diseases (ARD) with juvenile onset.

Methods: A total number of 117 consecutive patients from 2 tertiary referral hospitals were included in the study. All patients underwent genetic screening for type I C2 deficiency and C4 allotyping. Serum levels of immunoglobulin classes measured systematically throughout their regular medical care were recorded retrospectively.

Results: Our cohort of patients included 84 with juvenile idiopathic arthritis (JIA), 21 with systemic lupus erythematosus (SLE), 6 with systemic vasculitis, 2 with juvenile scleroderma, 2 with idiopathic uveitis, 1 with mixed connective tissue disease and 1 with SLE/scleroderma overlap syndrome. We have found 16 patients with evidence of primary immunodeficiency in our series (13.7\%), including 7 with C4 deficiency, 5 with selective IgA deficiency, 3 with C2 deficiency and 2 with unclassified hypogammaglobulinemia (one also presented C4D). Of the 84 patients with JIA, 4 (4.8\%) had a complement deficiency, which was less prevalent than in the SLE cohort $(23.8 \%)$, but all of them have exhibited an aggressive disease. Most of our patients with primary antibody deficiencies showed a more complicated and severe disease course and even the co-occurrence of two associated autoimmune diseases (SLE/scleroderma overlap syndrome and SLE/autoimmune hepatitis type 1 overlap).
\end{abstract}

Conclusions: Our findings among others demonstrate that complement and immunoglobulin immunodeficiencies need careful consideration in patients with ARD, as they are common and might contribute to a more severe clinical course of the disease.

Keywords: Primary complement, Antibody deficiency, Juvenile idiopathic arthritis, Juvenile onset systemic lupus erythematosus

\footnotetext{
* Correspondence: mihaelaspirchez@gmail.com

'2nd Department of Paediatrics, luliu Hatieganu University of Medicine and

Pharmacy, 3-5 Crisan Street, Cluj-Napoca 400177, Romania

${ }^{3}$ Emergency Children's Hospital, Cluj-Napoca, Romania

Full list of author information is available at the end of the article
}

\section{Biomed Central}

(C) 2015 Spârchez et al. Open Access This article is distributed under the terms of the Creative Commons Attribution 4.0 International License (http://creativecommons.org/licenses/by/4.0/), which permits unrestricted use, distribution, and reproduction in any medium, provided you give appropriate credit to the original author(s) and the source, provide a link to the Creative Commons license, and indicate if changes were made. The Creative Commons Public Domain Dedication waiver (http://creativecommons.org/publicdomain/zero/1.0/) applies to the data made available in this article, unless otherwise stated. 


\section{Background}

Primary immunodeficiencies (PIDs) are an inherited group of over 200 disorders that affect distinct components of the innate and adaptive immune system and predispose affected individuals to increased rate and severity of infection, immune dysregulation with autoimmune disease and malignancy $[1,2]$. Although they are generally recognized as rare disorders, higher prevalence are expected with the improvement of PIDs analysis [3]. Unfortunately, PIDs are widely underdiagnosed and undertreated [3]. Domain experts have done international collaborative efforts recently in order to increase awareness about the importance of early diagnosis and access to optimal care in these patients [3].

A significant proportion of patients presenting with an autoimmune condition have an underlying PID disorder that may not be clinically relevant [4] yet it may contribute to a more aggressive and worse prognosis [5]. Conversely, at present, strong evidence exist in favor of the notion that PIDs are more prevalent in patients with autoimmune conditions than in general population. Selective immunoglobulin A deficiency (SIgAD), the most common PID, has an estimated incidence ranging between 1:143 and 1:875 in the general European population, and much lower among Asian populations [6]. On the other hand, Liblau et al. reported SIgAD in $4.3 \%$ of patients with juvenile idiopathic arthritis (JIA) [7], whereas Cassidy et al. identified SIgAD in up to $5.2 \%$ of children with systemic lupus erythematosus (SLE) [8]. Other antibody deficiency syndromes have also been reported in association with autoimmune rheumatologic disorders (ARDs) as well. Complement deficiencies involving components of the classical pathway $(\mathrm{C} 1, \mathrm{C} 4$ or $\mathrm{C} 2$ ) have been recognized as one of the strongest genetic risk factor for SLE $[9,10]$, but have also been described with an increased frequency in rheumatoid arthritis (RA) population [11]. However, studies that specifically address the prevalence of complement deficiencies in JIA patients, the most common childhood rheumatic condition, are limited. One study of 35 JIA patients has reported a prevalence of $14.3 \%$ for C4 deficiencies [12] and in another two studies, C4 allotyping was considered in JIA population in order to find genetic susceptibility factors for the disease $[13,14]$.

The traditional diagnostics of complement deficiencies using serum $\mathrm{C} 3$ and $\mathrm{C} 4$ levels and $\mathrm{CH} 50$ activity was demonstrated not to be adequate to detect $\mathrm{C} 4$ and/or C2 deficiency in one study of Boeckler et al. [15] on SLE patients, allowing the diagnosis in a limited number of cases. Instead, the authors recommend $\mathrm{C} 4$ protein allotyping and genetic screening for type I C2 deficiency to be performed in investigative studies of primary complement deficiency states. According to Johnson et al. [16] this molecular bias is the most common cause of inherited C2 deficiency, occurring in over $90 \%$ of C2- deficient individuals.

Therefore, we performed a prospective study in order to assess the prevalence and clinical relevance of inherited complement and antibody deficiency states in a large series of patients with various ARDs with juvenile onset.

\section{Methods}

\section{Study population}

This was a prospective observational cohort study. A total number of 117 consecutive patients with paediatric-onset autoimmune rheumatologic diseases (ARD) were included in the study. Our cohort of patients was recruited from 2 tertiary referral hospitals for rheumatologic patients across Cluj-Napoca, Romania, over 1 year (Emergency Children's Hospital and the Rheumatology Unit of the Emergency Clinical County Hospital). The study was approved by the local Ethical Committee of the Iuliu Hatieganu University of Medicine and Pharmacy. Written informed consent has been obtained prior to their inclusion in the study as appropriate.

The onset of disease before 16 years of age and a well define diagnosis of ARD based on the revised ILAR criteria for JIA [17], new SLICC classification criteria for classification of SLE [18], EULAR/PRINTO/PRES classification criteria for childhood vasculitis [19], PRES/ACR/ EULAR provisional classification criteria for juvenile systemic sclerosis (jSSc) [20] were the inclusion criteria. Patients with recent blood transfusions and incomplete or unavailable medical records were excluded from this study.

\section{Data collection}

Medical records were obtained for evaluation from the attending physician. Demographic characteristics, family history of autoimmune diseases, PIDs and consanguinity, patient medical history (in particular infectious events, other associated autoimmune conditions, allergic diseases), diagnosis and history of present illness, drug therapy history since disease onset, associated conditions and complications were recorded for each patient. With regard to infections, we were interested in those that would arouse suspicion of PID: recurrent bacterial infections, mycobacterial infections, chronic mucocutaneous or invasive fungal infections and other opportunistic infections.

Furthermore, patient's charts were retrospectively reviewed for the immunological investigations performed as part of the diagnosis process, before initiating immunosuppressive therapy and afterwards, during the period of follow-up. Therefore, we registered the following immunological parameters: total serum levels of IgG, IgA, IgM, IgE, C3, C4, circulating immune complexes (CIC) and rheumatoid factor (RF). All patients included in the study have had C3, C4 and Ig levels tested at the diagnosis of AID. When available, serum levels of IgG2 and IgG4 were also noted. 
In addition, the autoantibodies profile of patients focusing on the antinuclear antibodies (ANA) panel, anti-cyclic citrullinated peptide (CCP) antibodies, anti-dsDNA antibodies (dsDNA), antiphospholipid antibodies (APLAs) and organ-specific autoantibodies [anti-endomysium (EmA), anti-gastric parietal cells (GPC), anti-smooth muscle (ASMA), anti-mitochondrial (AMA), antiliver-kidney microsomal (LKM1), anti-thyroid peroxidase (TPO)] was recorded too. The latter tests were performed depending on the clinical symptoms and anamnesis, according to the treating physician.

Reference ranges for the immunological tests analysed by immunoturbidimetry were as follows: $90-180 \mathrm{mg} / \mathrm{dl}$ for C3, $10-40 \mathrm{mg} / \mathrm{dl}$ for $\mathrm{C} 4$ and $<18 \mathrm{IU} / \mathrm{ml}$ for RF. The serum levels of Ig were interpreted based on patient's age. Autoantibodies test results were considered on their relation to the reference range of specific laboratory where the tests were done. The diagnosis of PID was established based on the new clinical diagnosis criteria for the European Society for Immunodeficiencies (ESID) registry [21]. Accordingly, the clinical criteria for a probable diagnosis of SIgAD were (1) at least one of the following: increased susceptibility to infection, autoimmune manifestations, affected family member; (2) diagnosis after 4th year of life; (3) undetectable serum IgA (when measured with nephelometry less than $0.07 \mathrm{~g} / \mathrm{L}$ ) but normal serum IgG and IgM (measured at least twice); (4) secondary causes of hypogammaglobulinaemia have been excluded; and (5) normal IgG antibody response to vaccination [21]. Unclassified hypogammaglobulinaemias was established in respect to the following criteria: (1) one of the following: recurrent infections, autoimmune phenomena (especially cytopenias), lymphoproliferation/ lymphoma; (2) marked decrease of at least one of IgG, IgG subclass (es), IgA or IgM levels (measured at least twice); (3) secondary causes of hypogammaglobulinaemia have been excluded; (4) normal isohaemagglutinins or/ and antibody response to vaccines; and (5) normal $\mathrm{T}$-cells and normal naive T cells.

\section{Genetic analyses}

Blood sample collection for the genetic analyses was performed during the routine visits in the hospital. Genomic DNA was extracted from peripheral blood using a Wizard ${ }^{\circ}$ Genomic DNA Purification kit (Promega) according to manufacturer instructions with minor modifications.

\section{Detection of type I C2 deficiency}

PCR technique was used to detect the type I C2 deficiency (28 bp deletion that removes last 9 bp of exon 6 and first $19 \mathrm{bp}$ of the intron 6 , the translated protein is truncated). The PCR reactions were performed in $25 \mu \mathrm{l}$ containing $1.5 \mathrm{mM} \mathrm{MgCl} 2,0.2 \mathrm{mM}$ dNTPs, $0.5 \mu \mathrm{M}$ of each primer, $1 \mathrm{U}$ of Dream Taq polymerase (ThermoScientific) and
100 ng of gDNA. The primers and PCR amplification program used were described previously [15]. The PCR products were detected by agarose gel electrophoresis (2 \%).

\section{Detection of C4 Deficiencies}

The PCR reactions were performed in $25 \mu \mathrm{l}$ as described above for $\mathrm{C} 2$ deficiency. The primers used for PCR amplification were described previously [22]. A touchdown PCR was performed starting with initial denaturation at $95{ }^{\circ} \mathrm{C}$ for $4 \mathrm{~min}$, followed by 6 cycles of $94{ }^{\circ} \mathrm{C}$ for $30 \mathrm{~s}$, $68{ }^{\circ} \mathrm{C}-1{ }^{\circ} \mathrm{C} /$ cycle, $72{ }^{\circ} \mathrm{C}$ for $40 \mathrm{~s}$; and 35 cycles of $94{ }^{\circ} \mathrm{C}$ for $30 \mathrm{~s}, 63{ }^{\circ} \mathrm{C}$ for $1 \mathrm{~min}, 72{ }^{\circ} \mathrm{C}$ for $40 \mathrm{~s}$; final extension $5 \mathrm{~min}$ at $72{ }^{\circ} \mathrm{C}$. The PCR products were detected by agarose gel electrophoresis (1.5\%). Patients with normal C4 alleles produced 2 fragments (377 and $578 \mathrm{bp}$ ) or no PCR amplification at patients with $\mathrm{C} 4$ deficiencies.

\section{Statistical methods}

Numerical variables such as age and disease duration were summarized by mean, median and range. Dichotomous variables were provided as frequency (in percentage). The overall infectious complication rate express the percent of patients with significant infectious events in different groups. Small subsets of patients with PID did not allowed us to make any meaningful comparisons.

\section{Results}

Our cohort included 84 patients with JIA (44\% female, 30 oligoarticular JIA, 23 polyarticular JIA, 18 systemiconset JIA, 9 enthesitis-related arthritis, 1 psoriatic arthritis, 3 undifferentiated arthritis), 21 patients with SLE (90\% female), 6 patients with systemic vasculitis ( $83 \%$ female), 2 patients with juvenile scleroderma (one boy with localised scleroderma and one girl with jSSc), 2 patients with idiopathic uveitis (both boys), 1 girl with mixed connective tissue disease (MCTD) and 1 girl with SLE/localized scleroderma overlap syndrome. All of them were Caucasions of European ancestry. Mean age at autoimmune disease onset was 8 years old with range between 0.7 and 16. Median duration of follow-up was 4 years, with range between 0.5 and 40 years.

We have found 16 patients with evidence of PID in our series. The distribution of PIDs among various juvenile-onset ARDs are presented in Table 1.

Out of the 16 PID patients, only 2 were boys. With the exception of patient 6 and 7, our PIDs patients had no family history of PID. The overall infectious complication rate was $43.75 \%$ in the PID patients and only $5 \%$ in the cohort with no evidence of PID. The age at autoimmune disease onset in the PID patients has ranged between 0.7 and 16 years of age. One SIgAD patient had an infantile onset and four patients had the onset of symptoms at 2-7 years of age. Duration of follow-up in 
Table 1 Prevalence of PIDs among the 117 patients with various juvenile-onset autoimmune rheumatologic diseases

\begin{tabular}{|c|c|c|c|c|c|c|}
\hline & $\begin{array}{l}\text { Total } \\
(n=117)\end{array}$ & $\begin{array}{l}\mathrm{JIA} \\
(n=84)\end{array}$ & $\begin{array}{l}\text { SLE } \\
(n=21)\end{array}$ & $\begin{array}{l}\text { Vasculitis } \\
(n=6)\end{array}$ & $\begin{array}{l}\text { MCTD } \\
(n=1)\end{array}$ & $\begin{array}{l}\text { Scleroderma/SLE } \\
\text { overlap syndrome }\end{array}$ \\
\hline & n (\%) & n (\%) & n (\%) & n (\%) & & $(n=1)$ \\
\hline PIDs & $16(13.7)$ & $6(7.2)$ & $6(28.6)$ & $2(33.3)^{a}$ & 1 & 1 \\
\hline C4D & $7(6)$ & $3(3.6)$ & $3(14.3)$ & $1(16.6)$ & 0 & 0 \\
\hline$C 2 D$ & $3(2.6)$ & $1(1.2)$ & $2(9.5)$ & 0 & 0 & 0 \\
\hline SlgAD & $5(4.3)$ & $2(2.4)$ & $1(4.8)$ & 0 & 1 & 1 \\
\hline Unclassified hypogamma globulinaemia & $2(1.7)$ & 0 & 0 & $2(33.3)$ & 0 & 0 \\
\hline
\end{tabular}

PID primary immunodeficiency, C4D C4 complement deficiency, C2D C2 complement deficiency, SIgAD selective immunoglobulin A deficiency

${ }^{a}$ One patient with vasculitis has been diagnosed with hypogammaglobulinemia, also complete C4B deficiency

the PID group was between 0.5 and 30 years. The diagnosis of inherited antibody deficiency was established concomitant with the AID diagnosis in patient 1, 3, 4, 5 and 6 or previous to AID onset in patient 2 (at 8 years old) and patient 7 (at 4 years old). The primary complement deficiencies were diagnosed at the time of this study in all patients. Detailed clinical and immunological characteristics of our PID patients and also the significant infection episodes are described in Table 2.

Unclassified hypogammaglobulinaemia has been designated in two siblings (patient 6 and 7), both with ANCAnegative systemic vasculitis. Both sisters have demonstrated persistently reduced IgM [the mean IgM level during the disease course was $11 \mathrm{mg} / \mathrm{dl}$ (range 5-22) in patient 6 and $27 \mathrm{mg} / \mathrm{dl}$ (range 20-35) in patient 7; the normal range for their age was $23-190 \mathrm{mg} / \mathrm{dl}$ in patient 6 and $50-260 \mathrm{mg} / \mathrm{dl}$ in patient 7] and IgA [the mean IgA level was $9 \mathrm{mg} / \mathrm{dl}$ (range 2-18) in patient 6 and $20 \mathrm{mg} / \mathrm{dl}$ (18-43) in patient 7; the normal range for their age was $23-190 \mathrm{mg} / \mathrm{dl}]$, decreased IgG4 $(<0.6 \mathrm{mg} / \mathrm{dl}$ in patient 6 and $2 \mathrm{mg} / \mathrm{dl}$ in patient 7; normal range 3-157 mg/dl). Patient 6 also had reduced IgG2 $(61 \mathrm{mg} / \mathrm{dl}$, normal range 65-220 mg/dl) and complete C4BD. Total serum IgG levels were not constantly reduced below $500 \mathrm{mg} / \mathrm{dl}$ in patients 6 and 7, although in patient 6 they were occasionally decreased (the lowest value was $326 \mathrm{mg} / \mathrm{dl}$ ).

Homozygous C2D was identified in one girl (patient 8) with SLE onset at 12 years of age, prominent photodermatitis and articular involvement and positive anti-Ro antibodies. Two other patients had heterozygous C2D (patient 9 and 10). Patient 9 was a girl with SLE and significant nephritis within 2 years after onset who underwent renal transplantation. Patient 10 was a boy with RF negative polyarticular JIA, with positive ANA in low titres, with still on-going active arthritis eleven years after onset.

Complete $\mathrm{C} 4 \mathrm{~B}$ deficiency was found in four patients. Apart from patient 6, there was one SLE female patient (patient 11), one systemic JIA patient (patient 12) and one girl with oligoarticular JIA (patient 13). Of the 3 patients with partial C4A deficiency, one had an undifferentiated form of JIA (patient 16) and two patients had
SLE (patient 14 and 15). Notably, patient 15 had associated SLE and autoimmune hepatitis type I.

Patients with SIgAD had the following diagnoses: one SLE/scleroderma overlap syndrome (IgA between 0 and $5 \mathrm{mg} / \mathrm{dl}$ ), one SLE associated with autoimmune hepatitis type I (IgA between 0 and $7 \mathrm{mg} / \mathrm{dl}$ ), one systemic-onset JIA (IgA between 2 and $6 \mathrm{mg} / \mathrm{dl}$ ), one MCTD (IgA $=5 \mathrm{mg} / \mathrm{dl}$ ), one oligoarticular JIA $(\operatorname{IgA}=4 \mathrm{mg} / \mathrm{dl})$. Of note, two of them associated allergic asthma.

Notably, the association of overall PID was greater in the SLE patient population relative to the JIA group of patients (28.6 \% versus $7.2 \%)$. In particular, C4D, C2D and also SIgAD were more prevalent in SLE group of patients than in the JIA cohort.

Among the 6 patients with positive RF in our JIA cohort, 2 were diagnosed with PID: patient 5 with SIgAD and patient 16 with partial C4AD. Acute anterior uveitis occurred in 9 JIA patients ( 2 with PID and 7 without PID). Infectious events, associated autoimmune conditions other than JIA, complications including macrophage activation syndrome and secondary amyloidosis occurred in very low numbers only in JIA population withough PID. The associated autoimmune diseases found in our JIA patients were type I diabetes mellitus and autoimmune thyroiditis.

Two SLE-PID patients presented with pulmonary tuberculosis at 14 years (patient 15) and 35 years of age (patient 14), respectively. It is important to note that in both cases there were no other risk factors for acquiring the infection. Moreover, two patients with SLE and PID associated autoimmune hepatitis type I (patient 2 with SIgAD and patient 15 with partial C4A D).

The small number of patients with PID did not allowed us to make any meaningful comparisons regarding clinical and immunological features of the disease.

\section{Discussion}

Over the past decades, there has been an increasing interest in the field of immunopathology providing a better understanding of the mechanisms that underlie diseases such as immunodeficiency, autoimmunity, autoinflammation or cancer. This was reflected in adding new disease entities, 
Table 2 Clinical and immunological characteristics of the 16 patients with PID in our series

\begin{tabular}{|c|c|c|c|c|c|c|c|}
\hline & \multirow{2}{*}{\multicolumn{2}{|c|}{ PID }} & $\begin{array}{l}\text { Autoimmune disease with clinical } \\
\text { and laboratory features }\end{array}$ & \multirow[t]{2}{*}{$\begin{array}{l}\text { Age at } \\
\text { AID onset }\end{array}$} & \multirow[t]{2}{*}{$\begin{array}{l}\text { Duration of follow } \\
\text { up (years) }\end{array}$} & \multirow[t]{2}{*}{$\begin{array}{l}\text { Autoantibody } \\
\text { profile }\end{array}$} & \multirow[t]{2}{*}{$\begin{array}{l}\text { Infectious events } \\
\text { indicative of PID }\end{array}$} \\
\hline & & & Associated conditions and complications & & & & \\
\hline \multirow[t]{4}{*}{1} & \multirow[t]{4}{*}{$\mathrm{F}$} & \multirow[t]{4}{*}{$\operatorname{Slg} A D$} & SLE/scleroderma overlap syndrome & \multirow{4}{*}{$\begin{array}{l}5 \text { for LS } \\
16 \text { for } \\
\text { SLE }\end{array}$} & \multirow[t]{4}{*}{24} & ANAs & $\begin{array}{l}\text { Urinary tract } \\
\text { infections }\end{array}$ \\
\hline & & & \multirow{3}{*}{$\begin{array}{l}\text { Raynaud phenomena, generalized } \\
\text { morphea, lupus nephritis, } \\
\text { microangiopathic haemolytic anaemia, } \\
\text { secondary antiphospholipidic syndrome, } \\
\text { systemic arterial hypertension, diffuse } \\
\text { interstitial pulmonary fibrosis, } \\
\text { pulmonary hypertension }\end{array}$} & & & dsDNA & \multirow{3}{*}{$\begin{array}{l}\text { Pneumonias from } \\
\text { an early age }\end{array}$} \\
\hline & & & & & & $\begin{array}{l}\text { Sm, RNP, } \\
\text { Histone }\end{array}$ & \\
\hline & & & & & & Nucleosome & \\
\hline \multirow[t]{3}{*}{2} & \multirow[t]{3}{*}{$\mathrm{F}$} & \multirow[t]{3}{*}{ SlgAD } & $\begin{array}{l}\text { SLE associated with autoimmune } \\
\text { hepatitis type } 1\end{array}$ & \multirow[t]{3}{*}{16} & \multirow[t]{3}{*}{2} & $\begin{array}{l}\text { ANAs, Sm, } \\
\text { U1 RNP }\end{array}$ & \multirow{3}{*}{$\begin{array}{l}\text { Urinary tract } \\
\text { infections prior } \\
\text { to AID diagnosis }\end{array}$} \\
\hline & & & \multirow{2}{*}{$\begin{array}{l}\text { lupus malar rash, photosensitivity, } \\
\text { synovitis, lymphopenia, } \\
\text { low complement }\end{array}$} & & & $\begin{array}{l}\text { Ribosomal } \\
\text { P protein }\end{array}$ & \\
\hline & & & & & & $\begin{array}{l}\text { Nucleosome, } \\
\text { ACA, ASMA }\end{array}$ & \\
\hline 3 & $\mathrm{~F}$ & SlgAD & $\begin{array}{l}\text { Systemic-onset JIA: polyarticular course, } \\
\text { chronic bilateral iridocyclitis with bilateral } \\
\text { cataract formation and band } \\
\text { keratopathy, loss of vision }\end{array}$ & 0.7 & 16 & $\mathrm{ANAs}^{\mathrm{a}}$ & No \\
\hline \multirow[t]{4}{*}{4} & \multirow[t]{4}{*}{$\mathrm{F}$} & \multirow[t]{4}{*}{ SlgAD } & \multirow{4}{*}{$\begin{array}{l}\text { MCTD: polyarthritis, livedo reticularis, } \\
\text { Raynau d's phenomenon, alopecia, } \\
\text { Gottron's papules, rash of dermatomyositis, } \\
\text { one psychotic episo de, aseptic necrosis of } \\
\text { the hip, direct Coombs 's test, intermittent } \\
\text { low C3 Allergic Asthma }\end{array}$} & \multirow[t]{4}{*}{14} & \multirow[t]{4}{*}{13} & ANAs, & \multirow{4}{*}{$\begin{array}{l}\text { Esophageal } \\
\text { candidiasis after } \\
\text { AID therapy }\end{array}$} \\
\hline & & & & & & dsDNA & \\
\hline & & & & & & U1 RNP & \\
\hline & & & & & & ANCAs & \\
\hline 5 & M & SlgAD & $\begin{array}{l}\text { Undifferentiated JIA: oligoarthritis, } \\
\text { positive RF Allergic Asthma }\end{array}$ & 9 & 1.5 & No & No \\
\hline 6 & $\mathrm{~F}$ & $\begin{array}{l}\text { Unclassified } \\
\text { hypogammaglobulinaemia } \\
\text { Complete C4BD }\end{array}$ & $\begin{array}{l}\text { Systemic vasculitis (ANCA negative): } \\
\text { fever, myalgia, a rthralgia, livedo reticularis, } \\
\text { maculopapular rash, III and VI cranial nerve } \\
\text { palsy, transient ischemic attack, } \\
\text { haemorrhagic stroke with right hemiparesis, } \\
\text { thrombocytopenia, nodular regenerative } \\
\text { hyperplasia of the liver, splenomegaly, } \\
\text { growth retardation }\end{array}$ & 2.5 & 4 & No & $\begin{array}{l}\text { Pneumonias prior } \\
\text { to AID diagnosis }\end{array}$ \\
\hline 7 & $\mathrm{~F}$ & $\begin{array}{l}\text { Unclassified } \\
\text { hypogammaglobulinaemia }\end{array}$ & $\begin{array}{l}\text { Systemic vasculitis (ANCA negative): fever, } \\
\text { myalgia, livedo reticularis, cutaneous } \\
\text { nodules, systemic arterial hypertension, } \\
\text { abdominal recurrent pain, massive } \\
\text { intestinal bleeding; bicuspid aortic valve } \\
\text { disease with aortic valve insufficiency }\end{array}$ & 6.5 & 2 & No & $\begin{array}{l}\text { Severe Epstein-Barr } \\
\text { virus-induced } \\
\text { acute infectious } \\
\text { mononucleosis at } \\
\text { the age of } 3\end{array}$ \\
\hline \multirow[t]{2}{*}{8} & \multirow[t]{2}{*}{$\mathrm{F}$} & \multirow[t]{2}{*}{ Homozygous C2D } & \multirow{2}{*}{$\begin{array}{l}\text { SLE: photosensitive lupus rash, oral ulcers, } \\
\text { synovitis, perniosis, serum high CIC levels }\end{array}$} & 12 & 2.5 & ANAs & No \\
\hline & & & & & & SS-A, Ro 52 & \\
\hline 9 & $\mathrm{~F}$ & Heterozygous C2 D & SLE: malar rash, synovitis, lupus nephritis, & 12 & 2.5 & ANAs $^{b}$ & No \\
\hline & & & $\begin{array}{l}\text { thrombocytopenia, leukopenia, hemolytic } \\
\text { anemia, low serum C } 3 \text { and C } 4 \text { levels, serum } \\
\text { high CIC levels, renal transplantation }\end{array}$ & & & dsDNA & \\
\hline 10 & M & Heterozygous C2 D & $\begin{array}{l}\text { Seronegative polyarticular JIA, Bronchogenic } \\
\text { cyst with surgical resection in infancy }\end{array}$ & 8 & 11 & $\begin{array}{l}\text { ANAs in } \\
\text { low titers }\end{array}$ & No \\
\hline 11 & $\mathrm{~F}$ & Complete C4B deficiency & $\begin{array}{l}\text { SLE: lupus nephritis, polisynovitis, } \\
\text { photosensitive lupus rash, low serum C3 } \\
\text { and C4 levels, serum high CIC levels, }\end{array}$ & 12 & 1.5 & $\begin{array}{l}\text { ANAs, dsDNA, } \\
\text { Histone, } \\
\text { pANCA }\end{array}$ & No \\
\hline & & & secondary antıphospholıpidıc syndrome & & & $A C A, \beta 2 G P$ & \\
\hline 12 & $\mathrm{~F}$ & Complete C4B deficiency & $\begin{array}{l}\text { Systemic-onset JIA: fever, polyarthritis, } \\
\text { evanescent rash, myalgias }\end{array}$ & 7 & 9 & No & No \\
\hline 13 & $\mathrm{~F}$ & Complete C4B deficiency & Oligoarticular JIA & 1.5 & 0.5 & No & No \\
\hline
\end{tabular}


Table 2 Clinical and immunological characteristics of the 16 patients with PID in our series (Continued)

\begin{tabular}{|c|c|c|c|c|c|c|c|}
\hline \multirow{3}{*}{\multicolumn{2}{|c|}{$14 \mathrm{~F}$}} & \multirow[t]{3}{*}{ Partial C4A deficiency } & \multirow{3}{*}{$\begin{array}{l}\text { SLE: Raynaud phenomena, lupus nephritis, } \\
\text { systemic arterial hypertension, secondary } \\
\text { vasculitis, synovitis, livedo reticularis, } \\
\text { pericarditis, secondary antiphospholipidic } \\
\text { syndrome, low serum C3 and C4 levels }\end{array}$} & \multirow[t]{3}{*}{10} & \multirow[t]{3}{*}{30} & $\begin{array}{l}\text { ANAs, Ro } \\
\text { (SS-A) }\end{array}$ & \multirow{3}{*}{$\begin{array}{l}\text { Pulmonary } \\
\text { tuberculosis at } \\
35 \text { years old }\end{array}$} \\
\hline & & & & & & $\begin{array}{l}\text { dsDNA, } \\
\text { pANCA }\end{array}$ & \\
\hline & & & & & & $A C A-\lg G$ & \\
\hline 15 & $\mathrm{~F}$ & Partial C4A deficiency & $\begin{array}{l}\text { SLE associated with autoimmune hepatitis } \\
\text { type 1: fever, synovitis, lupus malar rash, } \\
\text { oral ulcers, serositis, haemolytic anaemia, } \\
\text { secondary cutaneous vasculitis, Libman-- } \\
\text { Sacks endocarditis }\end{array}$ & 15 & 5 & $\begin{array}{l}\text { ASMA, ACA, } \\
\text { ANAs }^{s}\end{array}$ & $\begin{array}{l}\text { Pulmonary } \\
\text { tuberculosis at } \\
15 \text { years old }\end{array}$ \\
\hline 16 & $\mathrm{~F}$ & Partial C4A deficiency & $\begin{array}{l}\text { Undifferentiated JIA: oligoarthritis, positive } \\
\text { RF, bilateral chronic iridocyclitis with loss of } \\
\text { vision }\end{array}$ & 7.3 & 3 & $A N A s^{\S}$ & No \\
\hline
\end{tabular}

AlH autoimmune hepatitis, ACA anti-cardiolipin antibodies, ANAs antinuclear antibodies, C4D C4 deficiency, C2D C2 deficiency; CVID common variable immunodeficiency, dsDNA antibodies to double stranded DNA, F female, Ig Immunoglobulin, JIA Juvenile Idiopathic Arthritis, LS localized scleroderma, $M$ male, MCTD mixed connective tissue disease, RF rheumatoid factor, SIgAD selective IgA deficiency, SLE systemic lupus erythematosus, $\beta 2$ GP anti- $\beta 2$-glycoprotein I antibodies

${ }^{a}$ Negative ANA profile test (immunoblot), despite high titers of ANAs on indirect immunofluorescence (1/1280; homogeneous pattern)

${ }^{\mathrm{b}}$ ANAs profile not available

modern diagnostic strategies and novel immunotherapies that are being constantly developed. Although the spectrum of PIDs has been steadily expanding, a substantial number of patients remain undiagnosed.

We believe that this is the largest JIA cohort of patients investigated for both primary $\mathrm{C} 2$ and $\mathrm{C} 4$ complement components deficiencies. Of the 84 patients with JIA evaluated in the present study, $4.8 \%$ have had genetic evidence of early complement deficiency, which was less prevalent than in our SLE patients (23.8\%). This may be regarded as a significant proportion, in comparison with the prevalence of complement deficiencies in general population, which has been calculated to be about $0.03 \%$ (excluding MBL deficiency) [23]. In our series, C4D has been associated with JIA in $3.6 \%$ of the cases, unlike the higher prevalence of $14.3 \%$ reported in one previous study [12], using the same previously described primers for PCR amplification [22]. This variability may be explained by the difference in the total number of patients investigated (84 vs 35 ) or different genetic background. The older studies offer divergent results regarding the association between JIA and null alleles at the C4A and C4B locus [13, 14]. Heterozygous C2D was found in only one patient with seronegative polyarticular JIA. There is a paucity of studies relating to complement deficiencies in JIA. Gilliam et al. believe that many researchers did not considered this association, because polyarticular and oligoarticular JIA does not have systemic vasculitis [12]. But, later on, the same authors demonstrated complement activation with a dominant role of the classical pathway in both polyarticular and oligoarticular subtypes of JIA [24]. In addition, another recent study found classical pathway up-regulated in systemic JIA too [25]. This data suggest greater than anticipated contributions of the complement pathways in the pathogenesis of JIA, regardless of the subtype. Given all that, it seems likely that dysregulation of the complement system in cases with defects of the pathway's components may exacerbate the disease process, due to inappropriate activation of the system and impaired dissolution of immune complexes that cumulate and maintain the synovial inflammation. Indeed, all our complement deficient JIA patients have had an aggressive disease by chronic continuous or polyphasic arthritis (patient 10 and 12), severe bilateral chronic iridocyclitis with loss of vision (patient 16) and very early onset of the disease (1.5 years of age in patient 13). Remarkably, none of these patients had any clinical warning signs for PID, besides the occurrence of autoimmune manifestations.

We have also found complement deficiencies in the $23.8 \%$ of the SLE patients and in another systemic vasculitis patient with concomitant unclassified hypogammaglobulinaemia and complete C4B deficiency. This was not surprising, since associations between systemic autoimmune diseases and any of the early components of the classical pathways are all recognised [23, 26]. For instance, homozygous $\mathrm{C} 2$ deficiency, which is the most frequent hereditary deficiency in classical complement pathway, was estimated to be associated with systemic autoimmune disease in around 15 to $40 \%$ of the cases [27]. Deficiencies of $\mathrm{C} 4$ are very rare but associated with a higher prevalence of SLE (75 \%) [26], and almost exclusively with the deficiency of C4A isotype [28]. In our SLE cases with C4D, 2 had a partial deficiency of the $\mathrm{C} 4 \mathrm{~A}$ isotype and one had a complete deficiency of $\mathrm{C} 4 \mathrm{~B}$ isotype. We did not observed in these patients a younger age at disease onset as previously noted [29]. Moreover, it has been suggested in complement deficient SLE patients less renal, pulmonary or pericardial involvement and more prominent annular photosensitive skin rashes [29]. On the contrary, we have noted severe lupus 
nephritis within two years after onset in two girls with heterozygous $\mathrm{C} 2 \mathrm{D}$ and complete $\mathrm{C} 4 \mathrm{BD}$ and mild lupus nephritis with a later onset during the disease course in the patient with partial C4AD. But patient 8 has adhered more closely to the earlier described pattern of SLE patients with homozygous C2D: dominate photosensitivity and articular involvement, no renal disease, presence of anti-Ro antibodies [26].

Primary antibody deficiencies that we have found in our cohort of patients consisted of 5 SIgAD cases and 2 unclassified hypogammaglobulinaemias in two siblings. Our data regarding the prevalence of SIgAD in our JIA and SLE patients were more consistent with the previous studies $[5,7,8]$. It is important to note that most of antibody deficient patients showed a more complicated and severe disease course, which may be, at least in part, an effect of the associated PID. Remarkably, one girl with localized scleroderma at the age of 5 years old has consecutively developed SLE with lupus nephritis, secondary antiphospholipidic syndrome, microangiopathic haemolytic anaemia, diffuse interstitial pulmonary fibrosis and pulmonary hypertension. Another SIgAD patient with a polyarthritis onset at the age of 14 developed over several years features of other connective tissue diseases, fulfilling the criteria of MCTD. Worthy of attention also are the sisters with systemic vasculitis from an early age with associated unclassified hypogammaglobulinaemias before immunosuppressive treatment was initiated, of which one had two stroke events at the age of 4 and recurrent cranial nerve palsies and the other had a severe episode of gastrointestinal haemorrhage. They could not be considered common variable immunodeficiency disorders (CVID) because total serum IgG levels were not constantly reduced below $500 \mathrm{mg} / \mathrm{dl}$, even though patient 6 developed a variety of autoimmune manifestations characteristic of CVID according to recent relevant literature [30], including persistent autoimmune thrombocytopenia, livedo reticularis with negative APLAs, splenomegaly, nodular regenerative hyperplasia of the liver, skin lesions with histopathological pattern of interstitial granulomatous dermatitis in association with vasculopathy. The recently described genetic disorder "deficiency of ADA2" is being considered in both sisters, but yet unproven [31].

Unlike patients with SLE, systemic vasculitis and both patients with MCTD and SLE/scleroderma overlap syndrome, recurrent infectious events were not associated with PIDs in our JIA patients. We would like to stress that the available observation period for some of the JIA patients with PID (patient 5, 13 and 16) was relatively short. But, as it has been suggested before, the autoimmunity may be the only manifestation of a PID and that the absence of repeated infections is not sufficient to exclude a PID [4]. Conversely, another matter of concern is the confounding impact of longer duration of follow up after diagnosis in developing infections. That by itself may have been increased the risk of infections in some patients (patient 1 and 4) due to longer immunosuppressive therapies and hospitalizations.

A better understanding of this paradoxical relationship between autoimmunity and immunodeficiency is needed in order to provide more explanations about the contributions of PID to disease expressivity. Until than, the most relevant aspect of this relationship for the clinician remains the implications of PID identifying in the follow-up of these patients, which can be quite diverse and individualistic. Patients with a known complement deficiency should be carefully monitored for development of other potential complications or associated conditions involving complement activation. For instance, in a large cohort of C2-deficient SLE patients with long-term follow-up, a high frequency of severe cardiovascular damage was found that could not be explained by common risk factors [32]. Moreover, clinical situations of PID with overlap between increased susceptibility to infection and autoimmunity may require special considerations in selecting the immunosuppressive and biologic therapy, patient education and clinical monitoring. Finally, the immunoglobulin therapy, the mainstay of treatment for primary hypogammaglobulinemias with decreased IgG production, has also proved to be efficacious in specific autoimmune and inflammatory diseases [33].

To our knowledge, the co-existing of autoimmune hepatitis type 1, SLE and PIDs (SIgAD or C4AD) that we have encountered in patient 2 and 15, has not been reported in the literature so far. There have been few reported cases of either AIH associated with SLE [34-37] or AIH and SIgAD [38] or AIH and C4 deficiency [39] or AIH, SIgAD and primary Sjogren's syndrome [40]. Between the two types of AIH, type 1 seems to be more often associated with other autoimmune diseases, while type 2 presents more commonly with IgA deficiency [41]. We acknowledge that AIH type 1 diagnosis in our SLE patients was made only on clinical, biochemical and serologic data and that the liver biopsy for a definitive diagnosis of $\mathrm{AIH}$ has not been done for objective reasons.

\section{Conclusion}

In conclusion, a significant number of our JIA patients had genetic evidence for $\mathrm{C} 2 \mathrm{D}$ or $\mathrm{C} 4 \mathrm{D}$ and all of them have exhibited an aggressive disease. However, further studies are needed to decipher the implications of this association on disease expression and outcome of these patients. Moreover, most of our patients with primary antibody deficiencies including SIgAD and unclassified hypogammaglobulinaemias showed a more complicated and severe disease course and even the co-occurrence of two autoimmune diseases (SLE/scleroderma overlap syndrome and SLE/AIH type 1 overlap). We also report the 
first two cases of SLE/AIH type 1 overlap associated with SIgAD and C4AD, respectively. Our findings among others demonstrate that complement and immunoglobulin immunodeficiencies need careful consideration in patients with ARDs, as they are common and might contribute to a more severe clinical course of the disease.

\section{Abbreviations}

ACR: American College of Rheumatology; ARD: Autoimmune rheumatologic disorder; C2D: C2 deficiency; C4D: C4 deficiency; ESID: European Society for Immunodeficiencies; EULAR: European League against Rheumatism; ILAR: International League of Associations for Rheumatology; JIA: Juvenile idiopathic arthritis; PID: Primary immunodeficiency; PRES: Paediatric Rheumatology European Society; PRINTO: Paediatric Rheumatology International Trials Organisation; RA: Rheumatoid arthritis; SlgAD: Selective immunoglobulin A deficiency; SLE: Systemic lupus erythematosus; SLICC: Systemic Lupus International Collaborating Clinics.

\section{Competing interests}

None of the authors has any potential financial conflict of interest related to this manuscript.

\section{Authors' contributions}

MS and SR have conceived and designed the study. MS has analyzed and interpreted data, drafted and revised the manuscript. IL carried out the molecular genetic analysis and helped to draft the manuscript. DD, AB, LD, $L M, M M T, C B, B S, C S, I F$ and $C L$ have participated in the data collection and interpretation, and enrolling patients. ZS has participated in the study design and drafting the manuscript. SR have coordinated the study and the writing of the paper, and revised the manuscript. All authors read and approved the final manuscript.

\section{Acknowledgements}

This paper was published under the frame of European Social Found, Human Resources Development Operational Programme 2007-2013; project no. POSDRU 159/1.5/S/138776.

\begin{abstract}
Author details
'2nd Department of Paediatrics, luliu Hatieganu University of Medicine and Pharmacy, 3-5 Crisan Street, Cluj-Napoca 400177, Romania. ${ }^{2}$ Molecular Biology Center, Interdisciplinary Research Institute on Bio-Nano-Sciences, Babes-Bolyai University Cluj-Napoca, Cluj-Napoca, Romania. ${ }^{3}$ Emergency Children's Hospital, Cluj-Napoca, Romania. ${ }^{4}$ Rheumatology Department, Emergency Clinical County Hospital, Cluj-Napoca, Romania. ${ }^{5}$ Department of Rheumatology, Iuliu Hatieganu University of Medicine and Pharmacy, Cluj-Napoca, Romania. ${ }^{6}$ 3rd Department of Internal Medicine, Iuliu Hatieganu University of Medicine and Pharmacy, Cluj-Napoca, Romania.
\end{abstract}

Received: 13 July 2015 Accepted: 16 November 2015 Published online: 21 November 2015

\section{References}

1. Arason G, Jorgensen GH, Ludviksson BR. Primary immunodeficiency and autoimmunity: lessons from human diseases. Scand J Immunol. 2010;71:317-28.

2. Casanova JL, Abel L. Primary Immunodeficiencies: A field in its infancy. Science. 2007;317:617-9.

3. Chapel H, Prevot J, Gaspar HB, Español T, Bonilla FA, Solis L, et al. Primary immune deficiencies - principles of care. Front Immunol. 2014;5:1-12.

4. Barsalou J, Saint-Cyr C, Drouin E, Le Deist F, Haddad E. High prevalence of primary immune deficiencies in children with autoimmune disorders. Clin Exp Rheumatol. 2011;29:125-30

5. Jesus AA, Liphaus B, Silva C, Bando SY, Andrade LE, Coutinho A, et al. Complement and antibody primary immunodeficiency in juvenile systemic lupus erythematosus patients. Lupus. 2011;20:1275-84

6. Yel L. Selective IgA deficiency. J Clin Immunol. 2010;30:10-6.

7. Liblau RS, Bach JF. Selective IgA deficiency and autoimmunity. Int Arch Allergy Immunol. 1992;99:16-27.

8. Cassidy JT, Kitson RK, Selby CL. Selective IgA deficiency in children and adults with systemic lupus erythematosus. Lupus. 2007;16:647-50.
9. Sullivan KE. Complement deficiency and autoimmunity. Curr Opin Pediatr. 1998;10:600-6.

10. Bussone G, Mouthon L. Autoimmune manifestations in primary immune deficiencies. Autoimmun Rev. 2009;8:332-6.

11. Rigby WFC, Wu YL, Zan M, Zhou B, Rosengren S, Carlson C, et al. Increased frequency of complement C4B deficiency in rheumatoid arthritis. Arthritis Rheum. 2012;64:1338-44.

12. Gilliam BE, Wolff AE, Moore TL. Partial C4 deficiency in juvenile idiopathic arthritis patients. J Clin Rheumatol. 2007;13:256-60.

13. Hall PJ, Burman SJ, Barash J, Briggs DC, Ansell BM. HLA and complement C4 antigens in polyarticular onset seronegative juvenile chronic arthritis: association of early onset with HLA-DRw8. J Rheumatol. 1989;16:55-9.

14. Arnaiz-Villena A, Gómez-Reino JJ, Gamir ML, Regueiro JR, Vicario JL, GómezReino FJ, et al. DR, C4, and Bf allotypes in juvenile rheumatoid arthritis. Arthritis Rheum. 1984;27:1281-5.

15. Boeckler P, Meyer A, Uring-Lambert B, Goetz J, Cribier B, Hauptmann G, et al. Which complement assays and typings are necessary for the diagnosis of complement deficiency in patients with lupus erythematosus? A study of 25 patients. Clin Immunol. 2006;121:198-202.

16. Johnson CA, Densen P, Hurford RK, Colten HR, Wetsel RA. Type I human complement C2 deficiency. A 28-base pair gene deletion causes skipping of exon 6 during RNA splicing. J Biol Chem. 1992;267:9347-53.

17. Petty RE, Southwood TR, Manners P, Baum J, Glass DN, Goldenberg J, et al. International league of associations for rheumatology classification of juvenile idiopathic arthritis: second revision, Edmonton, 2001. J Rheumatol. 2004;31:390-2.

18. Petri M, Orbai AM, Alarcõn GS, Merrill JT, Fortin PR, Bruce IN, et al. Derivation and validation of the systemic lupus international collaborating clinics classification criteria for systemic lupus erythematosus. Arthritis Rheum. 2012;64:2677-86.

19. Ozen S, Pistorio A, lusan SM, Bakkaloglu A, Herlin T, Brik R, et al. EULAR/ PRINTO/PRES criteria for Henoch-Schönlein purpura, childhood polyarteritis nodosa, childhood Wegener granulomatosis and childhood Takayasu arteritis: Ankara 2008. Part II: Final classification criteria. Ann Rheum Dis. 2010;69:798-806

20. Zulian F, Woo P, Athreya BH, Laxer RM, Medsger Jr TA, Lehman TJ, et al. The pediatric rheumatology european society/american college of rheumatology/european league against rheumatism provisional classification criteria for juvenile systemic sclerosis. Arthritis Rheum. 2007;57: 203-12.

21. Edgar D, Ehl S. ESID Registry - Working definitions for clinical diagnosis of PID, 2014. http://esid.org/Working-Parties/Registry/Diagnosis-criteria.

22. Barba GM, Braun-Heimer L, Rittner C, Schneider PM. A new PCR-based typing of the Rodgers and Chido antigenic determinants of the fourth component of human complement. Eur J Immunogenet. 1994;21:325-39.

23. Grumach AS, Kirschfink M. Are complement deficiencies really rare? Overview on prevalence, clinical importance and modern diagnostic approach. Mol Immunol. 2014;61:110-7.

24. Gilliam BE, Reed MR, Chauhan AK, Dehlendorf AB, Moore TL. Significance of complement components $\mathrm{Clq}$ and $\mathrm{C} 4$ bound to circulating immune complexes in juvenile idiopathic arthritis: Support for classical complement pathway activation. Clin Exp Rheumatol. 2011;29:1049-56.

25. Barnes MG, Grom AA, Thompson SD, Griffin TA, Pavlidis P, Itert L, et al. Subtype-specific peripheral blood gene expression profiles in recentonset juvenile idiopathic arthritis. Arthritis Rheum. 2009;60:2102-12.

26. Gupta S, Louis AG. Tolerance and autoimmunity in primary immunodeficiency disease: a comprehensive review. Clin Rev Allergy Immunol. 2013;45:162-9.

27. Pickering MC, Walport MJ. Links between complement abnormalities and systemic lupus erythematosus. Rheumatology (Oxford). 2000;39:133-41.

28. Yang Y, Chung EK, Zhou B, Lhotta K, Hebert LA, Birmingham DJ, et al. The intricate role of complement component C4 in human systemic lupus erythematosus. Curr Dir Autoimmun. 2004;7:98-132.

29. Pettigrew HD, Teuber SS, Gershwin ME. Clinical significance of complement deficiencies. Ann N Y Acad Sci. 2009;1173:108-23.

30. Xiao X, Miao Q, Chang C, Gershwin ME, Ma X. Common variable immunodeficiency and autoimmunity - an inconvenient truth. Autoimmun Rev. 2014;13:858-64.

31. Zhou Q, Yang D, Ombrello AK, Zavialov AV, Toro C, Stone DL, et al. Earlyonset stroke and vasculopathy associated with mutations in ADA2. N Engl J Med. 2014;370:911-20. 
32. Jönsson G, Sjöholm AG, Truedsson L, Bengtsson AA, Braconier JH, Sturfelt G. Rheumatological manifestations, organ damage and autoimmunity in hereditary C2 deficiency. Rheumatology (Oxford). 2007;46:1133-9.

33. Warnatz K, Ballow M, Stangel M, Bril V. 7(th) International immunoglobulin conference: poster presentations. Clin Exp Immunol. 2014;178(Suppl):139-40.

34. Chowdhary VR, Crowson CS, Poterucha JJ, Moder KG. Liver involvement in systemic lupus erythematosus: case review of 40 patients. J Rheumatol. 2008;35:2159-64

35. Efe C, Purnak T, Ozaslan E, Ozbalkan Z, Karaaslan Y, Altiparmak E, et al. Autoimmune liver disease in patients with systemic lupus erythematosus: a retrospective analysis of 147 cases. Scand J Gastroenterol. 2011;46:732-7.

36. Matsumoto T, Kobayashi S, Shimizu H, Nakajima M, Watanabe S, Kitami N, et al. The liver in collagen diseases: pathologic study of 160 cases with particular reference to hepatic arteritis, primary biliary cirrhosis, autoimmune hepatitis and nodular regenerative hyperplasia of the liver. Liver. 2000;20:366-73.

37. Takahashi A, Abe K, Saito R, Iwadate H, Okai K, Katsushima F, et al. Liver dysfunction in patients with systemic lupus erythematosus. Intern Med. 2013:52:1461-5.

38. López-Cepero Andrada JM, Salado Fuentes M, Benítez Roldán A, del Molino Fernández J. Selective immunoglobulin A deficiency associated with chronic autoimmune hepatitis. Med Clin (Barc). 2001;117:438-9.

39. Constans J, Bernard P, Bioulac-Sage P, Barcat D, Conri C. Familial autoimmune hepatitis and C4 deficiency. Rev Med Interne. 1998;19:731-3.

40. Wanchu A, Bambery P, Sud A, Chawla Y, Vaiphei K, Deodhar SD. Autoimmune hepatitis in a patient with primary Sjogren's syndrome and selective lgA deficiency. Trop Gastroenterol. 2015;19:62-3.

41. Longhi MS, Mieli-Vergani G, Vergani D. Autoimmune hepatitis. Curr Pediatr Rev. 2014;10:268-74.

\section{Submit your next manuscript to BioMed Central and we will help you at every step:}

- We accept pre-submission inquiries

- Our selector tool helps you to find the most relevant journal

- We provide round the clock customer support

- Convenient online submission

- Thorough peer review

- Inclusion in PubMed and all major indexing services

- Maximum visibility for your research 